\title{
Julia Sursis Nobre Ferro Bucher
}

A homenageada desta edição tem sobrenome imponente, assim como seu histórico profissional. Júlia Sursis Nobre Ferro Bucher-Maluschke nasceu em Belém do Pará, em 1941, e é professora emérita da Universidade de Brasília. Atuou em cursos de graduação e pós-graduação do Instituto de Psicologia, além de ter formação nas áreas da terapia familiar, Psicologia clínica e da saúde. Sua trajetória profissional, juntamente ao seu papel ímpar na construção e na consolidação da Psicologia brasileira, merece reconhecimento.

Nascida em família em que a maioria estudou Direito, desde muito cedo Julia se incomodava com as questões da interação humana que procuravam justiça para resolver os seus problemas. Não satisfeita com essa ótica, ingressou, em 1964, no curso de Filosofia na Pontifícia Universidade Católica do Rio de Janeiro à procura do sentido da vida. Anos mais tarde, descobriu a Psicologia e a sexologia como campos fundamentais para o conhecimento do ser humano, contribuindo para que pessoas com sofrimento psíquico pudessem se tornar conscientes de seu potencial de superação.

Dois anos depois, no último ano da universidade, Julia ganhou uma bolsa de estudos para a Universidade Católica de Louvain, na Bélgica, onde concluiu sua especialização em Sociologia pela Université Catholique de Louvain. Foram dez anos de vivência na Bélgica, além de ter passado por vários países como França, Alemanha e Suiça para complementar os estudos. Nesse período, Julia casou-se e teve dois filhos.

O perfil acadêmico de Júlia e o compromisso com a construção e a divulgação de conhecimento em Psicologia marcaram sua carreira. Em 1976, tornou-se professora da UnB, onde contribuiu para a estruturação do mestrado em Psicologia. Sua atuação foi de fundamental importância para a consolidação da Psicologia clínica. Nesse período, destaca-se sua participação como membro da comissão que estruturou o Programa de Pós-Graduação em Psicologia. Até hoje, Júlia trabalha voluntariamente como colaboradora, continuando as atividades de alunos de mestrado e doutorado.

Precursora da área de terapia conjugal e familiar no Brasil, criou o primeiro curso de formação do Centro-Oeste, que funcionava no subsolo de sua casa. Os primeiros terapeutas de casais e famílias surgiram dessa experiência pioneira. Ex-alunos são hoje docentes e terapeutas em várias instituições universitárias de Brasília e em outras partes do Brasil.

Dessa época até os dias atuais, Júlia considera que foram muitas as mudanças ocorridas, tanto na estrutura quanto na dinâmica familiar, sobretudo nas questões das novas constituições conjugais e familiares. Para ela, o trabalho nesse campo tornou-se mais complexo devido às necessidades de se trabalhar em conjunto com as redes sociais.

Em 1986, ajudou a fundar e também foi presidente do Centro Brasileiro de Estudos da Família. Além disso, participou ativamente da construção do Movimento de Terapia Familiar no Brasil, que resultou na criação, em 1994, da Associação Brasileira de Terapia Familiar. Logo em seguida, fez parte da Associação Regional de Terapia Familiar do Centro-Oeste.

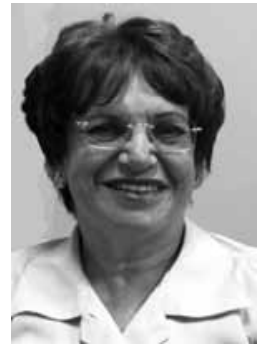

Após a aposentadoria, a professora foi convidada a trabalhar na Universidade Federal do Ceará, período de 1998 a 2002, onde desenvolveu pesquisas nas linhas de Psicologia da saúde, educação e promoção da saúde e metodologias qualitativas na pesquisa.

Nos Estados Unidos, realizou seu pós-doutorado, dedicando-se à pesquisa dos aspectos psicológicos decorrentes da AIDS. Essa trajetória possibilitou trazer para o Brasil novos conhecimentos, com o trabalho com pessoas HIV positivo e seus familiares, estudos sobre resiliência e sobre os modelos decorrentes da teoria dos sistemas e no campo da saúde pública. 